\title{
Isolation and Characterization of an Anaerobic, Cellulolytic Microorganism, Acetivibrio cellulolyticus gen. nov., sp. nov. $†$
}

\author{
G. B. PATEL, A. W. KHAN, B. J. AGNEW, AND J. R. COLVIN
}

Division of Biological Sciences, National Research Council of Canada, Ottawa, Ontario K1A OR6, Canada

A new genus of cellulolytic, gram-negative, nonsporeforming, anaerobic bacteria . is described. The colonies produced by these bacteria on cellulose agar were round, clear, translucent, and cream-colored and had an undulate margin. Single cells of the bacterium were straight to slightly curved rods 0.5 to $0.8 \mu \mathrm{m}$ wide by 4 to $10 \mu \mathrm{m}$ long and were motile by means of a single flagellum located one-third of the distance from the end of the cell. Among the various substrates tested, only cellulose, cellobiose, and salicin were able to support growth. The major fermentation products of cellobiose or cellulose degradation were acetic acid, hydrogen, and carbon dioxide. The deoxyribonucleic acid base composition of the type species was $38 \mathrm{~mol} \%$ guanine plus cytosine. The name Acetivibrio is proposed for this new genus, which is placed in the family Bacteroidaceae. The type species, Acetivibrio cellulolyticus sp. nov., is named on the basis of its cellulolytic activity. The type strain of A. cellulolyticus is CD2 (= NRC 2248).

A cellulolytic anaerobe from a methanogenic enrichment culture from municipal sewage sludge $(6,7)$ is described. This gram-negative, monotrichous rod produces acetic acid, hydrogen, and carbon dioxide from native cellulose, cellobiose, or salicin. No other carbohydrates tested were utilized. The isolate is described here under the name Acetivibrio cellulolyticus gen. nov., sp. nov. and is assigned to the family Bacteroidaceae as emended in 1976 (14).

\section{MATERIALS AND METHODS}

Media. The basal medium has the following composition (mg/liter, wt/vol): $\mathrm{NaHCO}_{3}, 2,060 ; \mathrm{NH}_{4} \mathrm{Cl}$, $680 ; \mathrm{K}_{2} \mathrm{HPO}_{4}, 296 ; \mathrm{KH}_{2} \mathrm{PO}_{4}, 180 ;\left(\mathrm{NH}_{4}\right)_{2} \mathrm{SO}_{4}, 150$; $\mathrm{MgSO}_{4} \cdot 7 \mathrm{H}_{2} \mathrm{O}, 120 ; \mathrm{CaCl}_{2} \cdot 2 \mathrm{H}_{2} \mathrm{O}, 61 ; \mathrm{FeSO}_{4} \cdot 7 \mathrm{H}_{2} \mathrm{O}, 21$; $\mathrm{N}\left(\mathrm{CH}_{2} \mathrm{COOH}\right)_{3}, 15 ; \mathrm{NaCl}, 10 ; \mathrm{MnSO}_{4} \cdot \mathrm{H}_{2} \mathrm{O}, 5 ; \mathrm{CoCl}_{2}$. $6 \mathrm{H}_{2} \mathrm{O}, 1 ; \mathrm{ZnSO}_{4} \cdot 7 \mathrm{H}_{2} \mathrm{O}, 1 ; \mathrm{CuSO}_{4} \cdot 5 \mathrm{H}_{2} \mathrm{O}, 0.1 ; \mathrm{AlK}\left(\mathrm{SO}_{4}\right)_{2} \cdot$ $12 \mathrm{H}_{2} \mathrm{O}, 0.1 ; \mathrm{H}_{3} \mathrm{BO}_{3}, 0.1 ; \mathrm{Na}_{2} \mathrm{MoO}_{4} \cdot 2 \mathrm{H}_{2} \mathrm{O}, 0.1$; pyridoxine $\mathrm{HCl}, 0.1$; thiamine $\mathrm{HCl}, 0.05$; riboflavin, 0.05 ; nicotinic acid, 0.05; $p$-aminobenzoic acid, 0.05; lipoic acid, 0.05 ; biotin, 0.02 ; folic acid, 0.02 ; vitamin $\mathrm{B}_{12}, 0.005$; and resazurin, 1 . This medium was found to produce the maximum and most rapid cellulose digestion in the original methanogenic mixed cultures (8). For isolation and culture maintenance, the basal medium was supplemented with $1 \mathrm{~g}$ of cellulose per liter prepared from absorbent cotton as described by Hungate (5) and $250 \mathrm{mg}$ of cysteine-hydrochloride and $250 \mathrm{mg}$ of $\mathrm{Na}_{2} \mathrm{~S} \cdot 9 \mathrm{H}_{2} \mathrm{O}$ (4) per liter as reducing agents. This medium, referred to as cellulose broth, was prereduced by the Hungate (5) technique, dispensed in $10-\mathrm{ml}$ amounts in $60-\mathrm{ml}$ serum vials (12) under $80 \% \mathrm{~N}_{2}-20 \%$ $\mathrm{CO}_{2}$ and autoclaved at $15 \mathrm{lb} / \mathrm{in}^{2}$ for $15 \mathrm{~min}$. For the preparation of solid media, the basal medium was supplemented with $18 \mathrm{~g}$ of agar, $2 \mathrm{~g}$ of cellulose, and

$\dagger$ Issued as NRCC no. 17999.
$0.25 \mathrm{~g}$ of cysteine-hydrochloride per liter, and the $\mathrm{pH}$ was adjusted to 7.5. The medium was autoclaved aerobically at $15 \mathrm{lb} / \mathrm{in}^{2}$ for $15 \mathrm{~min}$ and cooled to $50^{\circ} \mathrm{C}$, and $0.25 \mathrm{~g}$ of cysteine-hydrochloride $(20 \mathrm{ml}$ of a $1.25 \%$ cysteine-hydrochloride solution adjusted to $\mathrm{pH} 10$ and autoclaved under oxygen free $\mathrm{N}_{2}$ ) was added aseptically. Twenty milliliters of medium was poured into each sterile glass Petri dish $(90 \mathrm{~mm}$ in diameter). After the agar had solidified, the plates were placed in an anaerobic chamber (Coy Manufacturing Co., Ann Arbor, Mich.) containing $5 \% \mathrm{CO}_{2}-10 \% \mathrm{H}_{2}-85 \% \mathrm{~N}$. for a 24-h period to reduce the medium. The peptone-yeast extract (PY) broth was prepared as described by Holdeman and Moore (4), and 10-ml quantities were dispensed into serum vials or into modified test tubes (under $100 \% \mathrm{~N}_{2}$ or $80 \% \mathrm{~N}_{2}-20 \% \mathrm{CO}_{2}$ gas phase) having sealable necks, similar to those of serum vials, and autoclaved. The final $\mathrm{pH}$ of all media was $7.0 \pm 0.2$ at $25^{\circ} \mathrm{C}$

Isolation and stock culture maintenance. An established mixed culture described earlier (6) was used as a source of inoculum for isolation purposes. Serial dilution of the inoculum was made into the cellulose broth $(80 \%$ N.2-20\% CO. gas phase), and a $0.1-\mathrm{ml}$ quantity of each dilution was spread on the surface of prereduced cellulose agar plates inside the anaerobic chamber. The inoculated plates were placed inside Brewer anaerobic jars which were fitted with two one-way valves. The jars were flushed with an $80 \% \mathrm{~N} .20 \% \mathrm{CO}_{2}$ gas mixture and incubated at $35^{\circ} \mathrm{C}$. Colonies demonstrating cleared zones of cellulose digestion were individually picked (inside the anaerobic chamber) and transferred to cellulose broth. The broth was serially diluted and was then plated on cellulose agar. This procedure was repeated a few more times to ascertain purity of the culture by colony type and microscopic examination. A stock culture of the isolate (strain CD2) used in the present study was maintained by weekly transfer into cellulose broth 
under an $80 \% \mathrm{~N}_{2}-20 \% \mathrm{CO}$. gas phase. Unless stated otherwise, all tests were incubated at $35^{\circ} \mathrm{C}$.

Photo and electron microscopy. Cellulose agar colonies showing a cleared zone of cellulose digestion were photographed as follows. The petri dish was illuminated by dark-field lighting. Exposure was made through a $\times 1$ filter $(\lambda 550)$ at a magnification of $\times 1.5$ and recorded on Polaroid $55 \mathrm{P} / \mathrm{N}$ panchromatic film. The negative produced in a positive configuration because of dark-field illumination was contact printed on a blue-sensitive emulsion to create a positive negative to correct for proper tonal values in final printing in relation to the original petri dish. In each step of reproduction, contrast values were enhanced to provide prints of good photographic visibility.

Photomicrographs were also made of cellulose broth cultures by use of a Leitz Wetzlar microscope. To prevent movement of cells during photographing, the microscope slides used were coated with $2 \%$ (wt/vol) washed Nobel agar and air dried before application on cell suspension.

A 3-day-old culture grown without shaking in PY broth containing $1 \%$ cellobiose was used for electron microscopy. After dilution of the culture in distilled water, the cells were placed on Formvar films and dialyzed overnight. The films were placed on carboncoated grids, dried, shadowed at an angle of approximately $15^{\circ}$ with $\mathrm{Pd}-\mathrm{Au}$, and observed by a Seimens electron microscope, model 101.

Biochemical tests. Biochemical tests were made on PY broth fortified with substrate as required and used as described by Holdeman and Moore (4). Both $100 \% \mathrm{~N}_{2}$ and $80 \% \mathrm{~N}_{2}-20 \% \mathrm{CO}_{2}$ gas phases were used in these tests. Where the medium required a source of fermentable carbohydrate for a test (e.g., indole-nitrite broth), $0.5 \%$ cellobiose was incorporated. In these tests, the inoculum consisted of $0.04 \mathrm{ml}$ of a 72 -h-old cellulose broth culture. $\mathrm{H}_{2}$ and $\mathrm{CO}_{2}$ in the headspace were assayed by the method of van Huyssteen (17). Unless stated otherwise, all biochemical tests (volatile and nonvolatile acids, alcohols, acetylmethylcarbinol, catalase, ammonia, indole, nitrate reduction) were performed as described by Holdeman and Moore (4). Cultures showing turbid growth were assayed at 1 week or earlier, and all negative tests were incubated for up to 4 weeks. Media containing insoluble substrate such as cellulose were agitated at $200 \mathrm{rpm}$ on a rotary shaker.

Growth temperature and $\mathrm{pH}$ requirements. $\mathrm{PY}$ broth containing $1 \%$ cellobiose $\left(100 \% \mathrm{~N}_{2}\right.$ gas phase) was used as a growth medium so that the soluble substrate would permit measurement of growth by optical density $(660 \mathrm{~nm})$ determination. In these tests, the medium in the tubes was inoculated at $1 \%$ rate with a 72-h-old culture grown in PY cellobiose medium. The growth in test vessels was monitored on a daily basis for up to 14 days. For temperature studies, the $\mathrm{pH}$ of the PY-cellobiose broth was adjusted to 7.0 \pm 0.1 , and incubation was at 15 to $58^{\circ} \mathrm{C}$ in about $5^{\circ} \mathrm{C}$ increments. For pH studies, cultures in PY-cellobiose broth with $\mathrm{pH}$ adjusted to between 4.6 and 8.2 (at about $0.5 \mathrm{pH}$-unit increments) were incubated at $35^{\circ} \mathrm{C}$.

DNA base composition determination. For the determination of deoxyribonucleic acid (DNA) base ratios, cells grown for $72 \mathrm{~h}$ in cellulose broth under
$80 \% \mathrm{~N}_{2}-20 \% \mathrm{CO}_{2}$ were harvested and disrupted ultrasonically for $5 \mathrm{~min}$ in 30 -s bursts ( $95 \%$ breakage). The crude DNA from the lysate was extracted by Marmur's method (11) and purified on a 2- by 4-cm hydroxyapatite column (Bio-Rad Laboratories, DNA grade BioGel HTP) by the method of Markov and Ivanov (10). The base composition of the DNA was determined by ultraviolet spectroscopy (16). Three separate isolations of the DNA were carried out, and each isolation was tested twice. For comparison, DNA similarly extracted from Escherichia coli (freeze-dried cells of strain B [= ATCC 11303], stock no. EC-DNA-Sigma Chemical Co., St. Louis, Mo.) were also used for base composition determinations.

\section{RESULTS}

The technique of serial dilution of the mixed culture in cellulose broth and transfer to agar medium yielded a pure culture of a cellulolytic organism (strain CD2). Surface colonies of the isolate on cellulose agar were clearly visible after 3 to 4 weeks of incubation. These colonies were 1 to $2 \mathrm{~mm}$ in diameter and showed clearing zones of cellulose digestion extending from the colony periphery (Fig. 1) as well as into the agar below the colony. The colonies were round, raised, and cream colored and had an undulate margin. Growth of cells in cellulose broth under an $80 \%$ $\mathrm{N}_{2}-20 \% \mathrm{CO}_{2}$ gas phase resulted in the production of yellow pigment in the medium as well as on the cellulose particles.

The morphologies of the cells grown on agar and those grown in cellulose broth were identical (Fig. 2). Single cells were straight to slightly curved rods, 0.5 to 0.8 by 4 to $10 \mu \mathrm{m}$. Chains of cells up to $40 \mu \mathrm{m}$ in length could occasionally be observed in cellulose media. Young cells grown under non-shake culture conditions exhibited a tumbling motility and had a single flagellum per cell (Fig. 3A). The flagellum was located about one third of the distance from pole to pole and was approximately $6.9 \mu \mathrm{m}$ long (Fig. 3B). This location of the flagellum may explain the tumbling motility of the cells.

The isolate was catalase negative and gram negative. On negative staining with nigrosin, cells exhibited capsular material. No spores were detected, and 72-h- or 2-week-old cellulose and PY-cellobiose broth cultures failed to survive $80^{\circ} \mathrm{C}$ for $10 \mathrm{~min}$ or exposure to ethanol (9). The isolate did not grow under aerobic or microaerophilic conditions. It is an obligate anaerobe which requires prereduced media for growth.

The cells exhibited pleomorphism during cultivation on indole-nitrite broth fortified with $0.5 \%$ cellobiose under a $100 \% \mathrm{~N}_{2}$ or $80 \% \mathrm{~N}_{2}-20 \%$ $\mathrm{CO}_{2}$ gas phase. The organism predominantly grew in very long filaments with no evidence of septation and exhibited round swellings at var- 


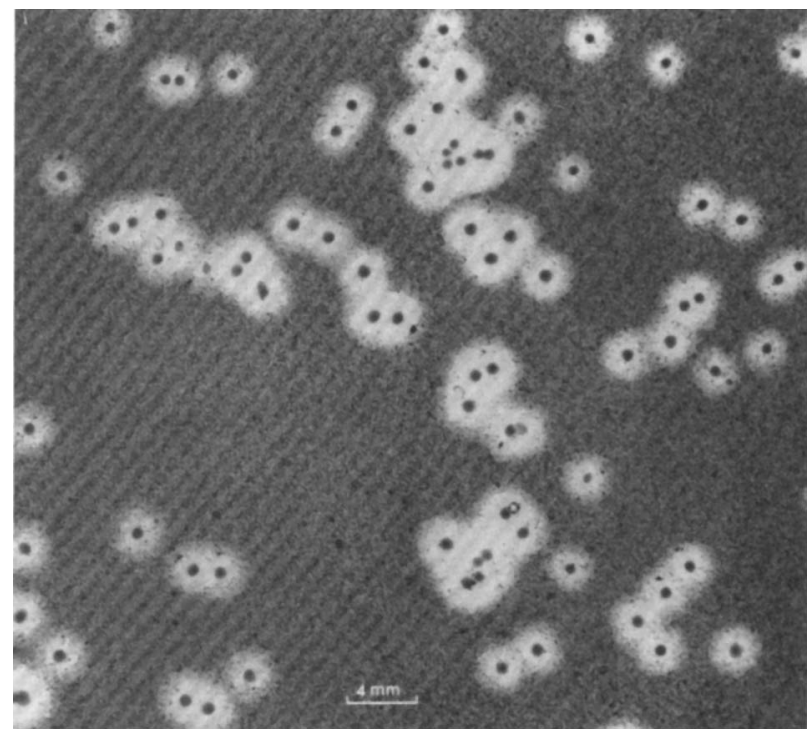

FIG. 1. Growth on agar showing clearing zone of cellulose digestion.

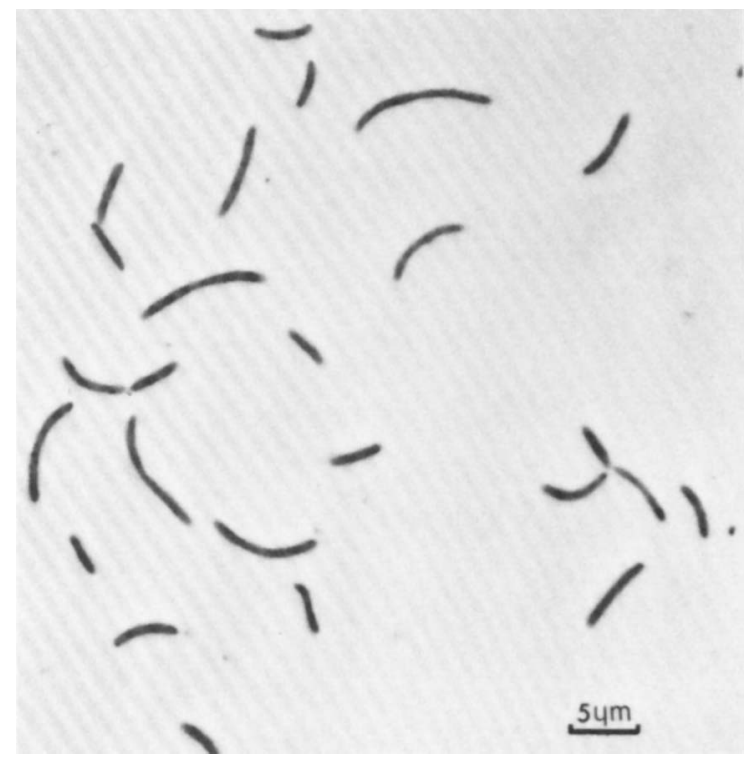

FIG. 2. Cell morphology of culture grown in cellulose broth.

ious points along the length of the filaments. This form of growth was particularly evident after 10 days of incubation. Growth as long cells without septa was occasionally observed in PYcellobiose broth. However these cells did not exhibit swellings as numerous as those seen in cells grown in the former medium. The transfer of pleomorphic cells grown in these media to cellulose broth resulted in the characteristic growth described earlier.
The biochemical characters of strain CD2 are presented in Table 1. PY without a fermentable carbohydrate failed to support growth. Of the various substrates tested, only cellulose, cellobiose, and salicin supported growth. However, PY-salicin broth could support growth under an $80 \% \mathrm{~N}_{2}-20 \% \mathrm{CO}_{2}$ gas phase but not under $100 \%$ $\mathrm{N}_{2}$. Addition of bile (2\% oxgall [Difco]) in PYcellobiose broth inhibited growth, whereas addition of Tween-80 or rumen fluid had no effect 
INT. J. Syst. BACTERIOL.
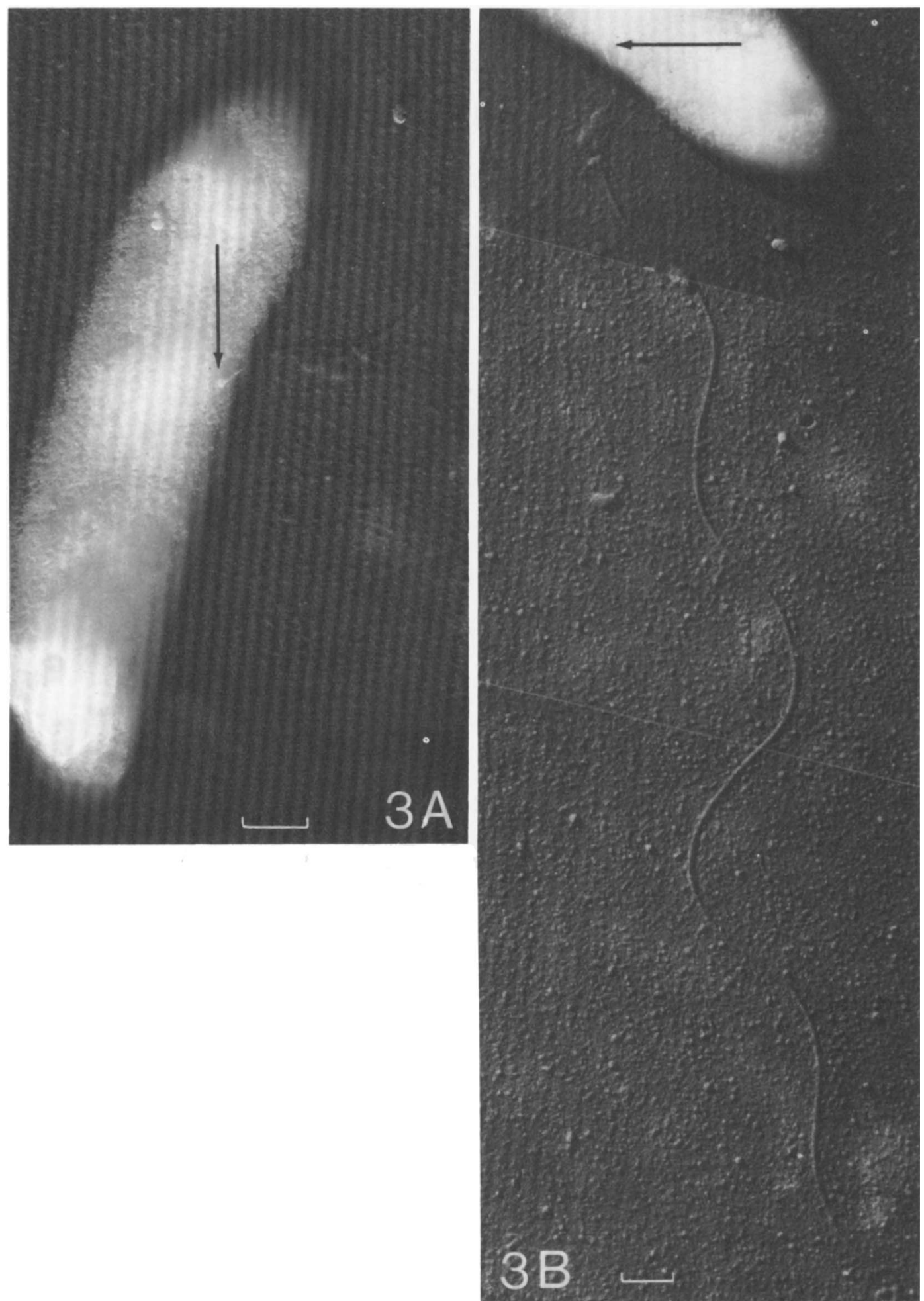

FIG. 3. Electron micrograph depicting the location and length of flagellum. (A) Assymetric attachment of the flagellum. The bar represents $250 \mathrm{~nm}(40,000 \times)$. (B) Length of the same flaggellum in a montage of three photographs. The bar represents $250 \mathrm{~nm}(32,000 \times)$. 
TABLE 1. Biochemical characteristics of strain CD2 grown at $35^{\circ} \mathrm{C}$ under an atmosphere of $80 \% \mathrm{~N}_{2}-20 \% \mathrm{CO} \cdot 2$

\begin{tabular}{|c|c|c|c|}
\hline Medium $^{a}$ & Growth $^{b}$ & $\begin{array}{c}\text { Acid } \\
\text { production }\end{array}$ & Comment \\
\hline PY & - & - & \\
\hline +Amygdalin & - & - & \\
\hline +Arabinose & - & - & \\
\hline +Cellobiose & + & + & Final pH after growth was 5.5 at $25^{\circ} \mathrm{C}$ \\
\hline+ Cellulose & + & + & Final $\mathrm{pH}$ after growth was 6.5 at $25^{\circ} \mathrm{C}$ \\
\hline +Fructose & - & - & \\
\hline +Galactose & - & - & \\
\hline +Glucose & - & - & \\
\hline +Glycogen & - & - & \\
\hline +Inositol & - & - & \\
\hline +Lactose & - & - & ' \\
\hline + Maltose & - & - & \\
\hline +Mannitol & - & - & \\
\hline +Mannose & - & - & \\
\hline +Melezitose & - & - & \\
\hline +Melibiose & - & - & \\
\hline+ Raffinose & - & - & \\
\hline +Rhamnose & - & - & \\
\hline +Ribose & - & - & \\
\hline+ Sucrose & - & - & \\
\hline +Trehalose & - & - & \\
\hline +Xylose & - & - & \\
\hline +Arginine & - & - & \\
\hline +Erythritol & - & - & \\
\hline +Glycerol & - & - & \\
\hline +Inulin & - & - & \\
\hline +Sorbitol & - & - & \\
\hline +Sorbose & - & - & \\
\hline +Starch-soluble & - & - & Iodine test was negative \\
\hline +Threonine & - & - & \\
\hline +Dulcitol & - & - & \\
\hline +Esculin & - & - & $\begin{array}{l}\text { Hydrolysis test with ferric ammonium citrate was } \\
\text { negative }\end{array}$ \\
\hline +Hippurate & - & - & \\
\hline +Salicin & + & + & Final pH after growth was 5.6 at $25^{\circ} \mathrm{C}$ \\
\hline +Lactate & - & - & \\
\hline +Pyruvate & - & - & \\
\hline +Urea & - & - & $\mathrm{pH}$ remained at 7.1 ; urease-negative \\
\hline +Cellobiose (no resazurin) & + & + & $\begin{array}{l}\text { Tests for acetylmethylcarbinol, indole, and am- } \\
\text { monia production were negative }\end{array}$ \\
\hline Indole-nitrite $+0.5 \%$ cellobiose & + & $\mathrm{ND}^{d}$ & $\begin{array}{l}\text { Tests for indole production and nitrate reduction } \\
\text { were negative }\end{array}$ \\
\hline Thiogel $+0.5 \%$ cellobiose & + & ND & $\begin{array}{l}\text { Gelatin liquefaction test was negative up to } 1 \\
\text { month incubation period }\end{array}$ \\
\hline $\mathrm{H}_{2} \mathrm{~S}$ medium $+0.3 \%$ cellobiose & - & ND & $\begin{array}{l}\text { No growth. } \mathrm{H}_{2} \mathrm{~S} \text { could not be detected by gas } \\
\text { chromatography in other media where growth } \\
\text { occurred. }\end{array}$ \\
\hline Chopped meat broth & - & ND & \\
\hline Milk & - & ND & \\
\hline
\end{tabular}

a All media were prepared as per Holdeman and Moore (4), and cellobiose was used as a substrate where medium required a fermentable carbohydrate source.

${ }^{b}$ No growth $(-)$; positive $(+)$ growth by microscopic examination and/or turbidity.

'Acid production positive $(+)$ if the drop in $\mathrm{pH}$ was $\geq 0.5 \mathrm{pH}$ units compared with inoculated PY medium as a control.

${ }^{d}$ Not determined.

on growth. Although vitamin K-heme (4) was not essential for growth in PY-cellobiose broth, it appeared to reduce the lag period.

Tests made to study the stability of strain
CD2 showed that this organism could be successfully maintained by subculturing at 1-week intervals in basal broth containing cellulose or cellobiose under an $80 \% \mathrm{~N}_{2}-20 \% \mathrm{CO}_{2}$ gas phase. 
The culture as maintained in basal broth containing cellobiose $(1 \% \mathrm{wt} / \mathrm{vol})$, did not lose its ability to degrade cellulose when subsequently transferred to cellulose broth. However, the organism could be successfully cultivated in PYcellobiose medium for three successive transfers under a $100 \% \mathrm{~N}_{2}$ or $80 \% \mathrm{~N}_{2}-20 \% \mathrm{CO}_{2}$ gas phase (transferred at 1-week intervals with $2 \%$ inoculum). These results indicate that PY medium lacks some vital nutrients that are present in the basal medium.

Metabolic products detected in PY-cellobiose medium after 8 days of incubation under $100 \%$ $\mathrm{N}_{2}$ or $80 \% \mathrm{~N}_{2}-20 \% \mathrm{CO}_{2}$ were acetic acid, hydrogen, carbon dioxide, and traces of propanol and butanol. Succinic and lactic acids were not detected. Metabolic products detected in cellulose broth after 3 days of incubation under an $80 \%$ $\mathrm{N}_{2}-20 \% \mathrm{CO}_{2}$ gas phase were acetic acid, hydrogen, carbon dioxide, and traces of ethanol. Propanol, butanol, lactic acid, and succinic acid were not detected.

The $\mathrm{pH}$ for optimum growth of strain CD2 was around 7.0. At an initial $\mathrm{pH}$ of between 6.5 and 7.7 , there was a lag period of about $72 \mathrm{~h}$. There was no growth at $\mathrm{pH} 6.1$ or 8.2. The temperature range in which growth occurred was 20 to $40^{\circ} \mathrm{C}$, with the optimum at about $35^{\circ} \mathrm{C}$. There was no growth at $15^{\circ} \mathrm{C}$ or $43^{\circ} \mathrm{C}$.

The DNA base composition of strain CD2 was $38 \mathrm{~mol} \%$ guanine plus cytosine $(\mathrm{G}+\mathrm{C})( \pm 1.2, n$ $=6$ ).

\section{DISCUSSION}

On the basis of its morphological and other characteristics, the gram-negative, nonsporeforming, straight to slightly curved, monotrichous rod described herein is included in the family Bacteroidaceae Pribram (15) as emended in 1976 (14). However, the combined morphological and biochemical characteristics of the organism do not match the definitions of any of the existing genera $(3,14)$ of this family. Therefore, we propose the establishment of a new genus, Acetivibrio, for this monotrichous organism which produces acetic acid as one of its major metabolities of carbohydrate fermentation. The type species of this genus is Acetivibrio cellulolyticus sp. nov., so named for its cellulolytic properties. The proposed genus Acetivibrio parallels the genera Butyrivibrio and Succinivibrio $(3,14)$, which are based on butyric acid and succinic acid, respectively, as the major fermentation end products.

A. cellulolyticus appears to resemble species of the genus Bacteroides $(3,4)$. However, monotrichous organisms are excluded from this genus. $A$. cellulolyticus also differs distinctly from
Bacteroides succinogenes $(2,5)$-another celluloytic anaerobe-in being motile, in producing $\mathrm{H}_{2}$, in not using glucose or casein, and in not producing succinic acid. The species described here also differs from the unidentified cellulolytic anaerobes described by Betian et al. (1) with respect to motility, inability to ferment lactose, and failure to hydrolyze esculin. The formation of yellow pigment and the production of acetic acid and $\mathrm{CO}_{2}$ are common characteristics of $A$. cellulolyticus and the Y strains of cellulolytic, anaerobic rods isolated from marine environments (13). However, the cellulolytic isolate reported in this study differs from the Y strains described by Miyoshi (13) in being motile, in producing $\mathrm{H}_{2}$, in not liquefying gelatin, and in not producing isobutyric acid. A combined generic and specific description follows: Acetivibrio gen. nov. and Acetivibrio cellulolyticus sp. nov. (L. noun acetum, vinegar; M.L. mas. n. Vibrio genus of bacteria, vibrio; M.L. mas. n. acetivibrio, vinegar (acetic) vibrio; M.L. adj. cellulolyticus, cellulose-dissolving).

Morphology: straight to slightly curved rods measuring 4 to 10 by 0.5 to $0.8 \mu \mathrm{m}$. Chains of cells up to $40 \mu \mathrm{m}$ in length also occur. Gramnegative, monotrichous cells which exhibit tumbling motility. The flagellum is attached to the cell about one-third of the distance from pole to pole.

Colony characteristics: cream-colored, round, 1 to $2 \mathrm{~mm}$ in diameter, raised, with an undulate margin. A zone of cellulose digestion extending from the periphery of the colony is observed in cellulose agar.

DNA base composition: $38 \mathrm{~mol} \% \mathrm{G}+\mathrm{C}$.

$\mathrm{pH}$ relationships: optimum, around 7.0; minimum and maximum, around 6.5 and 7.7 , respectively.

Temperature relationships: Optimum, around $35^{\circ} \mathrm{C}$; minimum and maximum, 20 and $40^{\circ} \mathrm{C}$, respectively.

Physiology: obligately anaerobic; cellulose, cellobiose, and salicin serve as growth substrates.

Type strain: CD2. This strain has been deposited in the National Research Council (NRC) of Canada culture collection under the accession number 2248 .

Source: Methanogenic enrichment culture from sewage sludge.

\section{ACKNOWLEDGMENT}

The assistance of Mr. R. H. Whitehead and Mr. L. C. Sowden in taking photographs is appreciated.

\section{REPRINT REQUESTS}

Address reprint requests to: Dr. G. B. Patel, Division of Biological Sciences, National Research Council of Canada, Ottawa, Ontario K1A OR6, Canada. 


\section{LITERATURE CITED}

1. Betian, H. G., B. A. Linehan, M. P. Bryant, and L. V. Holdeman. 1977. Isolation of a cellulolytic Bacteroides sp. from human feces. Appl. Environ. Microbiol. 33: 1009-1010.

2. Bryant, M. P., and R. N. Doetsch. 1954. A study of actively cellulolytic rod-shaped bacteria of the bovine rumen. J. Dairy Sci. 37:1176-1183.

3. Holdeman, L. V., and W. E. C. Moore. 1974. Gramnegative anaerobic bacteria, p. 384-426. In R. E. Buchanan and N. E. Gibbons (ed.), Bergey's manual of determinative bacteriology. The Williams and Wilkins Co., Baltimore.

4. Holdeman, L. V., and W. E. C. Moore (ed.). 1975 Anaerobe laboratory manual, 3rd ed. Anaerobe Laboratory, Virginia Polytechnic Institute and State University, Blacksburg.

5. Hungate, R. E. 1950. The anaerobic mesophilic cellulolytic bacteria. Bacteriol. Rev. 14:1-49.

6. Khan, A. W. 1977. Anaerobic degradation of cellulose by mixed culture. Can. J. Microbiol, 23:1700-1705.

7. Khan, A. W., and T. M. Trottier. 1978. Effect of sulfur containing compounds on anaerobic degradation of cellulose to methane by mixed culture obtained from sewage sludge. Appl. Environ. Microbiol. 35:1027-1034.

8. Khan, A. W., T. M. Trottier, G. B. Patel, and S. M. Martin. 1979. Nutrient requirement for the degradation of cellulose to methane by a mixed population of anaerobes. J. Gen. Microbiol. 112:365-372.
9. Koransky, J. R., S. D. Allen, and V. R. Dowell, Jr. 1978. Use of ethanol for selective isolation of spore forming microorganisms. Appl. Environ. Microbiol. 35 762-765.

10. Markov, G. G., and I. G. Ivanov. 1974. Hydroxyapatite column chromatography in procedures for isolation of purified DNA. Anal. Biochem. 59:555-563.

11. Marmur, J. 1961. A procedure for the isolation of deoxyribonucleic acid from microorganisms. J. Mol. Biol. 3: 208-218.

12. Miller, T. L., and M. J. Wolin. 1974. A serum bottle modification of the Hungate technique for cultivating obligate anaerobes. Appl. Microbiol. 27:985-987.

13. Miyoshi, H. 1978. Characterization of anaerobic cellulolytic bacteria isolated from marine environments. Bull. Jpn. Soc. Sci. Fish. 44:197-202.

14. Moore, W. E. C., J. L. Johnson, and L. V. Holdeman. 1976. Emendation of Bacteroidaceae and Butyrivibrio and descriptions of Desulfomonas gen. nov. and ten new species in the genera Desulfomonas, Butyrivibrio, Eubacterium, Clostridium, and Ruminococcus. Int. J. Syst. Bacteriol. 26:238-252.

15. Pribram, E. 1933. Klassification der schizomyceten, p. 1143. F. Deuticke, Leipzig.

16. Ulitzur, S. 1972. Rapid determination of DNA base composition by ultraviolet spectroscopy. Biochim. Biophys. Acta 272:1-11.

17. van Huyssteen, J. J. 1967. Gas chromatographic separation of digestor gases using porous polymers. Water Res. 1:237-242. 